A N N A L E S

UNIVER S T ATIS M A R A E C URIE-SKŁODOW K A

LUBLIN - POLONIA

VOL. XXXI, 2

SECTIO J

2018

Uniwersytet Marii Curie-Skłodowskiej w Lublinie. Wydział Pedagogiki i Psychologii

\title{
AGNIESZKA BOCHNIARZ
}

ORCID: 0000-0002-5675-3314

agnieszka.bochniarz@poczta.umcs.lublin.pl

\section{Samoocena osób niepetnosprawnych ruchowo pracujacych zawodowo}

Self-esteem of Employed People with Movement Disabilities

\section{STRESZCZENIE}

Praca zawodowa stanowi dla jednostki istotny element jej życia, zapewnia bowiem bezpieczeństwo ekonomiczne, umożliwia zaspokajanie potrzeb, budowanie tożsamości, znalezienie sensu i celu, przyczynia się do rozwoju i ustawicznego uczenia się. Niestety, ciągle jeszcze wielu ludzi doświadcza ograniczeń w dostępie do pracy. Problem ten dotyka w sposób szczególny osoby niepełnosprawne, dla których aktywność zawodowa stanowi szansę na kompensację ograniczeń wynikających ze specyfiki niepełnosprawności, ale jest również ważnym czynnikiem budowania pozytywnej samooceny. Przedmiotem analizy empirycznej w niniejszym opracowaniu uczyniono zagadnienia związane z samooceną osób niepełnosprawnych ruchowo, będących rodzicami, pracujących zawodowo. W badaniach została wykorzystana Skala Samooceny SES M. Rosenberga w polskiej adaptacji I. Dzwonkowskiej, K. Lachowicz-Tabaczek i M. Łaguny.

Słowa kluczowe: uogólnione zasoby odpornościowe; samoocena; stresory; wydarzenia krytyczne; niepełnosprawność ruchowa; rodzina; praca

\section{WPROWADZENIE}

W życiu człowieka są wydarzenia, które mają istotne znaczenie dla jego dalszego funkcjonowania, wpływają bowiem na procesy przystosowania psychospołecznego oraz na zdrowie. Określa się je mianem wydarzeń krytycznych. Są one trudne i obciążające, ponieważ dotychczasowe sposoby postępowania okazują się nieefektyw- 
ne, w związku z czym jednostka jest zmuszona do dokonania zmian. Powszechnie uważa się, że do krytycznych wydarzeń życiowych, które wymagają od człowieka szczególnego wysiłku w ponownej adaptacji i nie należą do repertuaru codziennych zdarzeń, można zaliczyć m.in. śmierć współmałżonka, bliskiego członka rodziny lub przyjaciela, rozwód, separację, utratę pracy, przejście na emeryturę, zmianę charakteru i miejsca pracy, zmianę miejsca zamieszkania, chorobę lub uszkodzenie ciała, bycie ofiarą przemocy, a nawet zdawałoby się przyjemne i szczęśliwe zdarzenia, jak np. małżeństwo, narodziny dziecka czy urlop (Poprawa 2001, s. 104).

Szczególną rolę w doświadczaniu wydarzeń życiowych jako krytycznych przypisuje się procesowi ich subiektywnego interpretowania, na który składają się: nadawanie przez jednostkę znaczenia i wagi danemu wydarzeniu (pozytywne - negatywne - ambiwalentne, ważne - nieważne), subiektywny poziom obciążenia psychicznego, siła emocji i ich treść oraz dokonywanie atrybucji przyczyny wydarzenia pod kątem sprawstwa (zawinione - niezawinione) (Sęk 2001, s. 14-20).

Próbując zachować dynamiczną równowagę procesów życiowych na optymalnym poziomie funkcjonowania, człowiek sięga do swoich potencjałów, czyli uogólnionych zasobów odpornościowych (Borys 2010, s. 45; Juczyński 2009, s. 19). A. Antonovsky pod pojęciem tym rozumie „pieniądze, siłę ego, stabilizację kulturową, wsparcie społeczne itp. - wszystko, co pozwala skutecznie stawiać czoło różnorodnym stresorom" (Antonovsky 2005, s. 11). Uogólnione zasoby odpornościowe obejmują więc właściwości jednostki biologiczne (genetyczne, konstytucjonalne, immunologiczne i biochemiczne) i psychologiczne (cechy poznawcze, cechy osobowości) oraz cechy społeczno-kulturowe (więzi i wsparcie społeczne, religia, filozofia, sztuka). Usprawniają one proces radzenia sobie człowieka $z$ wymaganiami i wyzwaniami płynącymi ze środowiska zewnętrznego i wewnętrznego, czyli z jego ciała czy psychiki, pozwalając na skuteczne radzenie sobie ze stanem napięcia, nie dopuszczając do powstania przewlekłego stresu (Antonovsky 2005, s. 26, 28-29; Heszen, Sęk 2008, s. 78-79).

Zasoby, którymi dysponuje człowiek, z jednej strony mogą ułatwiać opanowanie czy znoszenie stresujących wydarzeń życiowych, przeciwdziałać powstawaniu ich negatywnych konsekwencji psychosomatycznych, zaś z drugiej - uodparniać go na ich doświadczanie, prowadząc do tego, że nie będą one spostrzegane jako szkodliwe i zagrażające (Poprawa 2001, s. 106).

Gospodarka zasobami obejmuje dwa cykle: zysków i strat. Według S.E. Hobfolla cykle te można przedstawić w formie spirali. Oznacza to, że tak strata, jak i zysk mają tendencję do powiększania się w kolejnych cyklach. Spirala strat odznacza się jednak większą dynamiką, a utrata zasobów jest przez człowieka zdecydowanie bardziej intensywnie odczuwana niż spirala zysków. Dlatego istotne jest, aby jednostka poprzez inwestowanie zasobów zabezpieczyła się przed ich utratą, kompensowała straty i powiększała wachlarz zasobów, jakimi dysponuje (Heszen, Sęk 2008, s. 147). 
Jednym z zasobów o podstawowym znaczeniu dla człowieka jest względnie stabilna i pozytywna samoocena. Pełni ona istotną rolę w regulacji jego zachowania, ponieważ podejmowane przez niego działania (zwłaszcza w sytuacjach nowych, nieznanych czy niepewnych) wymagają oceny własnych możliwości (Wrona-Polańska, Kaczmarska 2012, s. 126; Ogińska-Bulik, Juczyński 2010, s. 159).

E. Aronson, T.D. Wilson i R.M. Akert (1997, s. 21) pod pojęciem „samoocena" rozumieją dokonywanie przez jednostkę oszacowania własnej wartości pod kątem rozmiaru, w jakim spostrzega siebie jako osobę przyzwoitą, dobrą i kompetentną.

Dla N. Brandena samoocena oznacza znacznie więcej niż wewnętrzne poczucie własnej wartości. W pełni zrealizowana jest przekonaniem, że człowiek dorósł do życia i wymagań przez nie stawianych oraz zasługuje na szczęście, powodzenie, zaspokojenie swoich potrzeb i pragnień. Zdrowa samoocena koreluje - zdaniem Brandena $-\mathrm{z}$ racjonalizmem, realizmem, intuicją, kreatywnością, niezależnością, elastycznością, umiejętnością radzenia sobie ze zmianami, życzliwością i umiejętnością współpracy oraz umiejętnością przyznawania się do błędów i ich korygowania (Branden 2012, s. 19-20, 42, 59).

Ze względu na wykorzystanie w badaniach własnych Skali Samooceny (The Rosenberg Self-Esteem Scale) opracowanej przez M. Rosenberga w artykule przyjęto definicję samooceny tego autora. W jego ujęciu samoocena jest rozumiana jako globalna pozytywna lub negatywna percepcja własnej osoby. Stanowi zatem jeden z subiektywnych elementów koncepcji Ja. Rosenberg uważa, że na wysoką samoocenę składa się przekonanie jednostki o tym, że jest ona wartościową i wystarczająco dobrą osobą, co nie oznacza, że uważa siebie za lepszą od innych. Dla autora samoocena stanowi dyspozycję (strukturę), która jest w miarę stałą właściwością (Dzwonkowska, Lachowicz-Tabaczek, Łaguna 2008, s. 7, 15).

Samoocena może być rozpatrywana z uwzględnieniem jej podstawowych wymiarów na kontinuum: wysoka - niska, adekwatna - nieadekwatna, stabilna - niestabilna, pozytywna - negatywna, pewna - zagrożona. Samoocena wysoka lub niska występuje wówczas, gdy jednostka ocenia własną wartość i możliwości jako duże lub niewielkie. Jej poziom uzależniony jest od rzeczywistych możliwości człowieka oraz od tego, z jakim wzorem osobowym się porównuje i jakie stawia sobie wymagania. Samoocena adekwatna bądź nieadekwatna wiąże się ze stanem faktycznym, czyli z prawidłową oceną swoich możliwości, i rzutuje na efektywne lub nieefektywne funkcjonowanie człowieka oraz na jego przystosowanie do otoczenia. Z kolei samoocena stabilna charakteryzuje się względnie stałym systemem sądów i opinii na swój temat, niezależnie od nieoczekiwanych sytuacji zewnętrznych, w odróżnieniu od samooceny niestabilnej, która jest zależna od chwilowych sukcesów i porażek, nastrojów oraz opinii innych osób. Pozytywna bądź negatywna samoocena zależy od poziomu zgodności Ja z wzorcem, do którego osoba się porównuje. Jeśli jednostka zbliża 
się do idealnego wyobrażenia o sobie, wówczas siebie akceptuje. Natomiast gdy rozbieżność między Ja realnym i Ja idealnym jest duża, jednostka ocenia siebie negatywnie. Można wreszcie wyróżnić samoocenę pewną, gdy człowiek jest przekonany o swojej wartości, oraz zagrożoną, gdy tego przekonania mu brakuje (Kirenko, Sarzyńska 2010, s. 94-98).

Wpływ samooceny na postępowanie człowieka jest wielostronny. Sposób, w jaki jednostka spostrzega i ocenia siebie, oddziałuje na jej reakcje wobec stawianych przed nią zadań, charakter relacji z innymi ludźmi, skuteczność podejmowanych przez nią działań czy funkcjonowanie w różnych rolach społecznych. Dlatego osoby z wysoką samooceną poszukują wyzwań i bodźców w postaci ambitnych i wartościowych celów, są lepiej przygotowane, aby radzić sobie z problemami w sferze prywatnej i zawodowej, potrafią otwarcie i adekwatnie komunikować się z innymi (Kirenko, Sarzyńska 2010, s. 98; Branden 2012, s. 21-22).

Znaczenie samooceny jest szczególnie istotne w sytuacji osoby niepełnosprawnej ruchowo. Dysfunkcję narządu ruchu można interpretować jako stresor, który prowadzi do zachwiania lub utraty równowagi wewnętrznej i zewnętrznej jednostki, zmienia się bowiem sposób spostrzegania własnego ciała, co z kolei rzutuje na ocenę innych właściwości i możliwości oraz na ogólną ocenę własnej wartości, zasadniczo wpływając na psychospołeczne funkcjonowanie osoby (Kirenko 1998, s. 60-63; por. Majewicz 2002, s. 69-70; Kirenko, Wiatrowska 2015, s. 191-192).

Samoocena kształtuje się od samego początku życia człowieka. Mają na nią wpływ praktycznie wszystkie zdarzenia, uczucia i emocje, jakich on doświadcza. Często zadania, z którymi musi się zmierzyć osoba niepełnosprawna, są trudne, a czasami wręcz niemożliwe do zrealizowania, co wiąże się z obiektywnie istniejącymi lub subiektywnie postrzeganymi ograniczeniami. Do tego dochodzi nietolerancja społeczeństwa i funkcjonujący stereotyp osoby niepełnosprawnej jako nie w pełni samodzielnej i zależnej od pomocy otoczenia, a także różnorodne bariery architektoniczne. Ponadto do czynników mających wpływ na poziom samooceny osoby z niepełnosprawnością można zaliczyć: charakter interakcji rodzinnych i małżeńskich, postawy społeczne innych osób (np. kolegów, koleżanek, nauczycieli), rodzaj niepełnosprawności, czas jej trwania, stopień akceptacji swojej niepełnosprawności i ograniczeń, które z niej wynikają (Borowiecki, 2015, s. 124-125; Majewicz 2002, s. 73).

Jednym z problemów, z którym muszą się zmierzyć osoby z dysfunkcją narządu ruchu, jest brak w społeczeństwie pozytywnego obrazu rodzicielstwa osób niepełnosprawnych. W konsekwencji osoby te mogą wątpić w swoje kompetencje w zakresie realizowania ról rodzinnych. Badania przeprowadzone przez L. Marszałek pokazały, że niepełnosprawne kobiety doświadczające trudności w realizacji roli matki najczęściej zwracały uwagę na własne ograniczenia fizyczne, które utrudniały im opiekę nad dzieckiem. Wskazywały one m.in. na niemożność 
wykonywania czynności opiekuńczych wobec dziecka, brak właściwego nadzoru nad dzieckiem z powodu barier architektonicznych, ograniczenia $\mathrm{w}$ atrakcyjnym spędzaniu czasu wolnego z dzieckiem (wspólne spacery, wycieczki, zabawy, uprawianie sportu itp.). Nie stanowiło to jednak o zasadniczej jakości kontaktów z dziećmi. Bardziej trudności te były odczuwane przez badane kobiety niż przez ich dzieci (Marszałek 2006, s. 162).

Osoby niepełnosprawne są w szczególnie trudnej sytuacji na rynku pracy. $\mathrm{Z}$ jednej strony odczuwają bowiem problemy, które wynikają z ograniczeń lub utraty sprawności, zaś z drugiej muszą zmierzyć się z barierami w dostępie do pracy (Kirenko, Sarzyńska 2010, s. 9). A przecież praca zawodowa jest nieodłącznym elementem aktywności człowieka. Praca oraz jej wymierny efekt w postaci płacy jawi się jako sposób umożliwiający człowiekowi realizację określonych potrzeb, zarówno podstawowych (fizjologicznych, bezpieczeństwa), jak i wyższego rzędu (uznania i akceptacji, samorealizacji, poznawczych). Poprzez pracę jednostka kreuje siebie jako osobę w wymiarze społecznym, psychologicznym i kulturowym, dzięki niej może pokazać swoją wartość, często jest więc sposobem na budowanie wysokiej i pozytywnej samooceny. Zaangażowanie w pracę ma pozytywne znaczenie dla samopoczucia człowieka w trakcie wykonywania obowiązków, wiąże się z bezpośrednią lub pośrednią satysfakcją, jaka płynie z jej wykonywania, z wyższą jakością życia i mniejszym ryzykiem wypalenia zawodowego (Łaguna i in. 2015, s. 281).

Podjęcie pracy zawodowej i uzyskanie niezależności ekonomicznej odgrywa szczególnie istotną rolę dla niepełnosprawnych rodziców, ponieważ pozwala na należyte wypełnianie przez nich funkcji materialno-ekonomicznej własnymi środkami i bez pomocy z zewnątrz. Brak pracy negatywnie odbija się nie tylko na standardzie życia osoby niepełnosprawnej i jej rodziny, ale także może warunkować zmianę samooceny. Przejawiać się to będzie w zakresie różnych sfer funkcjonowania osoby niepełnosprawnej: poznawczej, emocjonalnej, społecznej i behawioralnej (Kirenko, Sarzyńska 2010, s. 99-100).

\section{MATERIAŁ I METODA BADAŃ}

Praca zawodowa dla osób niepełnosprawnych odgrywa istotną rolę, może być bowiem czynnikiem terapeutycznym i mobilizującym. Dzięki niej jednostka uruchamia swoje umiejętności, zdolności, sprawności i nawyki, uświadamia sobie swoją wartość, wzmacnia szacunek do siebie, ma szansę doświadczenia sukcesu. Wyniki badań pokazują, że osoby bezrobotne są apatyczne, niestabilne emocjonalnie, pełne napięć, lęków i obaw oraz częściej mają obniżoną samoocenę niż osoby pracujące. Brak pracy może prowadzić do utraty zaufania do własnej osoby, wiary w siebie i własną skuteczność, w słuszność podejmowanych decyzji i wyborów (Kirenko, Sarzyńska 2010, s. 99; Branden 2012, s. 39). 
Celem niniejszych badań była próba określenia samooceny osób niepełnosprawnych ruchowo pracujących zawodowo. W związku z tym kwestie, wokół których koncentruje się problematyka badań, dają się sprowadzić do głównego problemu badawczego, który zawiera się w pytaniu: Jaka jest samoocena osób niepełnosprawnych ruchowo aktywnych i biernych zawodowo w porównaniu do osób pełnosprawnych?

Zgodnie z obowiązującymi w metodologii badań zasadami ze względu na diagnostyczny charakter pytania nie sformułowano do niego hipotezy roboczej (Łobocki 2006, s. 127).

Realizując cel badań, posłużono się metodą sondażu diagnostycznego, obejmującego Skalę Samooceny SES M. Rosenberga w polskiej adaptacji I. Dzwonkowskiej, K. Lachowicz-Tabaczek i M. Łaguny. Skala ta jest wykorzystywana do pomiaru globalnej samooceny młodzieży i osób dorosłych. Służy ona do pomiaru samooceny jawnej, czyli świadomej, którą należy odróżnić od samooceny ukrytej, ujawniającej się w sposób spontaniczny, bez udziału świadomej autorefleksji. Arkusz testowy składa się z 10 twierdzeń, które dotyczą wartości, możliwości, umiejętności oraz emocji i przekonań w stosunku do własnej osoby. Badane osoby udzielają odpowiedzi z wykorzystaniem czterostopniowej skali: od ,zdecydowanie zgadzam się” do „zdecydowanie nie zgadzam się". Ocena odpowiedzi na twierdzenia sformułowane pozytywnie, zawarte w pytaniach 1, 2, 4, 6, 7, jest odwracana tak, aby wyższa wartość punktowa była przyznana za odpowiedzi, które wyrażają wyższy poziom samooceny. W polskiej wersji skali można uzyskać wyniki w przedziale od 0 do 40 pkt, przy czym im wyższą liczbę punktów uzyskuje badana osoba, tym wyższa jest jej samoocena. Chcąc ocenić, czy uzyskany przez nią wynik jest niski czy wysoki, należy się odwołać do norm. Biorąc pod uwagę wiek i płeć badanych, należy przekształcić otrzymany wynik surowy na skalę stenową, uwzględniając następującą interpretację wyników: steny 1 i 2 - wyniki bardzo niskie, steny 3 i 4 - wyniki niskie, steny 5 i 6 - wyniki przeciętne, steny 7 i 8 - wyniki wysokie, steny 9 i 10 - wyniki bardzo wysokie. Analiza wyników badań z wykorzystaniem polskiej wersji Skali Samooceny SES Rosenberga pokazuje, że mierzy ona w sposób zadowalający stosunek do własnej osoby oraz diagnozuje istotny aspekt koncepcji Ja (Dzwonkowska, Lachowicz-Tabaczek, Łaguna 2008, s. 7, 15, 31, 62-64; Góralewska-Słońska 2011, s. 103).

W badaniach własnych zastosowano celowy dobór próby, starając się wyodrębnić wśród badanych grupę rodziców z niepełnosprawnością ruchową aktywnych i biernych zawodowo oraz grupę rodziców pełnosprawnych pracujących i niepracujących.

Ogółem w badaniu wzięły udział 84 osoby, w tym 39 osób z niepełnosprawnością ruchową $(46,43 \%)$ i 45 pełnosprawnych $(53,57 \%)$. Jeśli chodzi o grupę podstawową, to było w niej 14 kobiet niepełnosprawnych ruchowo i 25 mężczyzn z niepełnosprawnością ruchową. Z kolei w grupie porównawczej znalazło się 21 kobiet i 24 mężczyzn (tab. 1). 
Tab. 1. Płeć badanych

\begin{tabular}{|c|c|c|c|c|c|c|}
\hline \multirow{2}{*}{ Płeć } & \multicolumn{2}{|c|}{ Kobiety } & \multicolumn{2}{c|}{ Mężczyźni } & \multicolumn{2}{c|}{ Ogółem } \\
\cline { 2 - 7 } & $\mathrm{N}$ & $\%$ & $\mathrm{~N}$ & $\%$ & $\mathrm{~N}$ & $\%$ \\
\hline Osoby niepełnosprawne ruchowo & 14 & 35,90 & 25 & 64,10 & 39 & 100 \\
\hline Osoby pełnosprawne & 21 & 44,44 & 24 & 55,56 & 45 & 100 \\
\hline
\end{tabular}

Źródło: opracowanie na podstawie badań własnych.

Tab. 2. Aktywność zawodowa badanych osób

\begin{tabular}{|c|c|c|c|c|c|c|c|c|c|c|c|c|c|c|c|}
\hline \multicolumn{4}{|c|}{ Osoby niepełnosprawne ruchowo } & \multicolumn{5}{c|}{ Osoby pełnosprawne } \\
\hline \multicolumn{3}{|c|}{ Kobiety } & \multicolumn{3}{c|}{ Mężczyźni } & \multicolumn{4}{c|}{ Kobiety } & \multicolumn{4}{c|}{ Mężczyźni } \\
\hline $\begin{array}{c}\text { Aktywne } \\
\text { zawodowo }\end{array}$ & $\begin{array}{c}\text { Bierne } \\
\text { zawodowo }\end{array}$ & $\begin{array}{c}\text { Aktywni } \\
\text { zawodowo }\end{array}$ & $\begin{array}{c}\text { Bierni } \\
\text { zawodowo }\end{array}$ & $\begin{array}{c}\text { Aktywne } \\
\text { zawodowo }\end{array}$ & $\begin{array}{c}\text { Bierne } \\
\text { zawodowo }\end{array}$ & \multicolumn{2}{c|}{$\begin{array}{c}\text { Aktywni } \\
\text { zawodowo }\end{array}$} & $\begin{array}{c}\text { Bierni } \\
\text { zawodowo }\end{array}$ \\
\hline $\mathrm{N}$ & $\%$ & $\mathrm{~N}$ & $\%$ & $\mathrm{~N}$ & $\%$ & $\mathrm{~N}$ & $\%$ & $\mathrm{~N}$ & $\%$ & $\mathrm{~N}$ & $\%$ & $\mathrm{~N}$ & $\%$ & $\mathrm{~N}$ & $\%$ \\
\hline 6 & 42,86 & 8 & 57,14 & 15 & 60 & 10 & 40 & 13 & 61,90 & 8 & 38,1 & 17 & 70,83 & 7 & 29,17 \\
\hline
\end{tabular}

Źródło: opracowanie na podstawie badań własnych.

W grupie osób z niepełnosprawnością ruchową 21 osób $(53,85 \%)$ było aktywnych zawodowo, w tym 6 kobiet i 15 mężczyzn. Również w grupie porównawczej zdecydowanie najwięcej badanych pracowało zawodowo - 30 osób $(66,67 \%)$ (tab. 2).

\section{WYNIKI BADAŃ WŁASNYCH}

Na samoocenę jednostki składa się wiara we własną skuteczność, czyli zaufanie do własnego umysłu, umiejętność myślenia, uczenia się, dokonywania wyborów, podejmowania decyzji, poleganie na sobie, szacunek do siebie, który przejawia się w ochronie własnych wartości, oraz umiejętność obrony swoich przekonań i potrzeb. Jest ona swoistym układem odpornościowym świadomości, dostarczając sił obronnych i możliwości regeneracji. Samoocena ma istotne znaczenie dla funkcjonowania jednostki, ponieważ warunkuje jej działania społeczne i zawodowe, kształtuje relacje $\mathrm{z}$ innymi ludźmi, a także prowadzi do konkretnych sposobów jej reagowania emocjonalnego (Branden 2012, s. 41; Góralewska-Słońska 2011, s. 97-98).

Dla uzyskania odpowiedzi na pytanie badawcze dotyczące samooceny osób z niepełnosprawnością ruchową dokonano porównania danych otrzymanych ze Skali Samooceny SES M. Rosenberga z danymi osób pełnosprawnych. Wykorzystano tu test parametryczny t-Studenta dla par niezależnych. 
Tab. 3. Samoocena osób niepełnosprawnych ruchowo i osób pełnosprawnych

\begin{tabular}{|c|c|c|c|c|c|c|}
\hline \multirow{2}{*}{ Samoocena } & \multicolumn{2}{|c|}{$\begin{array}{c}\text { Osoby niepełnosprawne } \\
\text { ruchowo }\end{array}$} & \multicolumn{2}{c|}{ Osoby pełnosprawne } & \multirow{2}{*}{$\mathrm{t}$} & $\mathrm{p}$ \\
\cline { 2 - 5 } & $\mathrm{M}$ & $\mathrm{SD}$ & $\mathrm{M}$ & $\mathrm{SD}$ & & \\
\hline T1 & 2,00 & 0,83 & 2,58 & 0,69 & $-3,489$ & 0,001 \\
\hline $\mathrm{T} 2$ & 2,05 & 0,79 & 2,60 & 0,72 & $-3,324$ & 0,001 \\
\hline T3 & 2,46 & 0,85 & 3,40 & 0,54 & $-6,104$ & 0,000 \\
\hline T4 & 2,23 & 0,74 & 3,07 & 0,50 & $-6,143$ & 0,000 \\
\hline T5 & 2,85 & 0,90 & 3,47 & 0,50 & $-3,950$ & 0,000 \\
\hline T6 & 2,18 & 0,76 & 3,04 & 0,60 & $-5,834$ & 0,000 \\
\hline T7 & 2,44 & 1,10 & 3,04 & 0,64 & $-3,161$ & 0,002 \\
\hline T8 & 2,54 & 0,88 & 3,40 & 0,62 & $-5,230$ & 0,000 \\
\hline T9 & 2,74 & 1,02 & 3,38 & 0,49 & $-3,712$ & 0,000 \\
\hline T10 & 2,59 & 0,97 & 3,38 & 0,49 & $-4,808$ & 0,000 \\
\hline Suma & 24,08 & 5,41 & 31,36 & 3,54 & $-7,392$ & 0,000 \\
\hline
\end{tabular}

Źródło: opracowanie na podstawie badań własnych. Wyniki badań dotyczące samooceny zostały opublikowane w: (Bochniarz, 2017, s. 159-169).

Analiza wartości średnich uzyskanych za pomocą Skali Samooceny SES M. Rosenberga (tab. 3) wskazuje, że badani z grupy podstawowej wykazują istotnie niższy poziom samooceny niż osoby z grupy porównawczej $(\mathrm{p}<0,000)$. Dokonując porównania szczegółowych obszarów samooceny w Skali M. Rosenberga, można zauważyć, że w zakresie lubienia siebie, poczucia zadowolenia, posiadania pozytywnych cech, bycia osobą wartościową, oceny własnych możliwości i umiejętności w wykonywaniu działań na poziomie zbliżonym do innych osób, poczucia dumy i szacunku do siebie samego osoby niepełnosprawne ruchowo w porównaniu do osób pełnosprawnych uzyskały niższe średnie wyniki, co wpływa istotnie na obniżenie wyniku globalnej samooceny.

Interesujące wydało się także poznanie, czy istnieją różnice pomiędzy poziomem samooceny badanych osób. Uzyskane wyniki badań, dotyczące poziomu samooceny osób niepełnosprawnych ruchowo i osób pełnosprawnych, wskazały na pewne różnice między porównywanymi grupami (tab. 4 i 5).

Zdecydowana większość (prawie 77\%) badanych rodziców niepełnosprawnych ruchowo oceniła stosunek do własnej osoby bardzo niekorzystnie $-46,16 \%$ badanych ma bardzo niski, a 30,77\% niski poziom samooceny. Warto odnotować, że 6 niepełnosprawnych kobiet, mających bardzo niski poziom samooceny, nie pracowało, zaś 4 były aktywne zawodowo. W grupie niepełnosprawnych mężczyzn 11 pracujących dysponowało bardzo niskim i niskim poziomem samooceny. Dla porównania 6 niepracujących badanych miało niską i bardzo niską samoocenę. Wśród niepełnosprawnych rodziców były tylko 2 osoby, które posiadały 
Tab. 4. Poziom samooceny osób niepełnosprawnych ruchowo i osób pełnosprawnych

\begin{tabular}{|c|c|c|c|c|c|c|}
\hline \multirow{2}{*}{ Poziom samooceny } & \multicolumn{2}{|c|}{ Osoby niepełnosprawne } & \multicolumn{2}{c|}{ Osoby pełnosprawne } & \multicolumn{2}{|c|}{ Ogółem } \\
\cline { 2 - 7 } & $\mathrm{N}$ & $\%$ & $\mathrm{~N}$ & $\%$ & $\mathrm{~N}$ & $\%$ \\
\hline Bardzo niski & 18 & 46,16 & 0 & 0 & 18 & 21,43 \\
\hline Niski & 12 & 30,77 & 5 & 11,11 & 17 & 20,24 \\
\hline Przeciętny & 7 & 17,95 & 23 & 51,11 & 30 & 35,71 \\
\hline Wysoki & 1 & 2,56 & 12 & 26,67 & 13 & 15,48 \\
\hline Bardzo wysoki & 1 & 2,56 & 5 & 11,11 & 6 & 7,14 \\
\hline Razem & 39 & 100,00 & 45 & 100,00 & 84 & 100,00 \\
\hline
\end{tabular}

Źródło: opracowanie na podstawie badań własnych.

Tab. 5. Poziom samooceny osób niepełnosprawnych ruchowo pracujących i niepracujących zawodowo oraz osób pełnosprawnych pracujących i niepracujących zawodowo

\begin{tabular}{|c|c|c|c|c|c|c|c|c|}
\hline \multirow[b]{2}{*}{$\begin{array}{c}\text { Poziom } \\
\text { samooceny }\end{array}$} & \multicolumn{4}{|c|}{ Osoby niepełnosprawne } & \multicolumn{4}{|c|}{ Osoby pełnosprawne } \\
\hline & 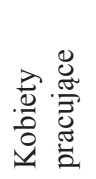 & 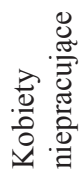 & 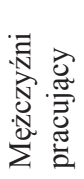 & 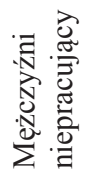 & 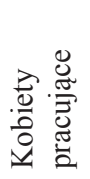 & 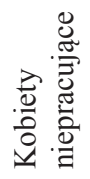 & 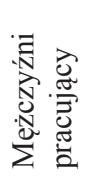 & 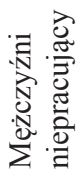 \\
\hline Bardzo niski & 4 & 6 & 3 & 5 & 0 & 0 & 0 & 0 \\
\hline Niski & 1 & 2 & 8 & 1 & 0 & 2 & 3 & 0 \\
\hline Przeciętny & 1 & 0 & 4 & 2 & 9 & 3 & 7 & 4 \\
\hline Wysoki & 0 & 0 & 0 & 1 & 4 & 3 & 2 & 3 \\
\hline Bardzo wysoki & 0 & 0 & 0 & 1 & 0 & 0 & 5 & 0 \\
\hline Razem & 6 & 8 & 15 & 10 & 13 & 8 & 17 & 7 \\
\hline
\end{tabular}

Źródło: opracowanie na podstawie badań własnych.

wysoki i bardzo wysoki poziom samooceny - byli to mężczyźni niepracujący zawodowo. W grupie rodziców pełnosprawnych najliczniejszą grupę stanowiły osoby o przeciętnym poziomie samooceny $(51,11 \%)$, z czego 9 kobiet i 7 mężczyzn było aktywnych zawodowo, zaś 3 kobiety i 4 mężczyzn to osoby bezrobotne. Dwanaście osób $(26,67 \%)$ wysoko oceniło stosunek do własnej osoby - 4 kobiety i 2 mężczyzn to osoby pracujące, zaś 3 kobiety i 3 mężczyzn nie pracowało.

Zastanawiając się nad tym, jakie czynniki decydują o samoocenie badanych osób, zwrócono uwagę na dwa: płeć oraz aktywność zawodową. W tym celu wykorzystano test Kołmogorowa-Smirnowa, który jest testem nieparametrycznym używanym do porównywania rozkładów jednowymiarowych cech statystycznych.

Dokonując porównania szczegółowych obszarów samooceny kobiet i mężczyzn niepełnosprawnych ruchowo, można zauważyć, że mężczyźni w zakresie lubienia siebie, poczucia zadowolenia, oceny własnych umiejętności i możliwo- 
Tab. 6. Samoocena kobiet i mężczyzn z grupy podstawowej

\begin{tabular}{|c|c|c|c|c|c|c|c|}
\hline \multirow{3}{*}{ Samoocena } & \multicolumn{4}{|c|}{ Osoby niepełnosprawne ruchowo } & \multirow{3}{*}{$\begin{array}{l}\text { Maks. } \\
\text { ujemna } \\
\text { różnica }\end{array}$} & \multirow{3}{*}{$\begin{array}{l}\text { Maks. } \\
\text { dodatnia } \\
\text { różnica }\end{array}$} & \multirow{3}{*}{$\mathrm{p}$} \\
\hline & \multicolumn{2}{|c|}{ Kobiety } & \multicolumn{2}{|c|}{ Mężczyźni } & & & \\
\hline & M & SD & M & SD & & & \\
\hline $\mathrm{T} 1$ & 2,00 & 0,78 & 2,00 & 0,87 & $-0,040$ & 0,034 & $\mathrm{p}>0,10$ \\
\hline $\mathrm{T} 2$ & 2,00 & 0,55 & 2,08 & 0,91 & $-0,137$ & 0,137 & $p>0,10$ \\
\hline $\mathrm{T} 3$ & 2,29 & 0,91 & 2,56 & 0,82 & $-0,134$ & 0,000 & $\mathrm{p}>0,10$ \\
\hline $\mathrm{T} 4$ & 2,07 & 0,62 & 2,32 & 0,80 & $-0,146$ & 0,000 & $\mathrm{p}>0,10$ \\
\hline T5 & 2,71 & 0,83 & 2,92 & 0,95 & $-0,177$ & 0,009 & $\mathrm{p}>0,10$ \\
\hline T6 & 2,07 & 0,62 & 2,24 & 0,83 & $-0,266$ & 0,097 & $\mathrm{p}>0,10$ \\
\hline $\mathrm{T} 7$ & 1,93 & 0,62 & 2,72 & 1,21 & $-0,400$ & 0,000 & $\mathrm{p}>0,10$ \\
\hline $\mathrm{T} 8$ & 2,29 & 0,73 & 2,68 & 0,95 & $-0,200$ & 0,000 & $\mathrm{p}>0,10$ \\
\hline T9 & 2,50 & 1,09 & 2,88 & 0,97 & $-0,363$ & 0,006 & $p>0,10$ \\
\hline $\mathrm{T} 10$ & 2,50 & 1,09 & 2,64 & 0,91 & $-0,243$ & 0,126 & $\mathrm{p}>0,10$ \\
\hline Suma & 22,36 & 3,79 & 25,04 & 5,98 & $-0,346$ & 0,137 & $p>0,10$ \\
\hline
\end{tabular}

Źródło: opracowanie na podstawie badań własnych.

ści, poczucia dumy, szacunku do własnej osoby, posiadania pozytywnych cech i bycia osobą wartościową uzyskali wyższe średnie, co wpływa na podniesienie wyniku ich globalnej samooceny. Najwyżej ocenioną wartością w przypadku badanych mężczyzn i kobiet $\mathrm{z}$ grupy podstawowej jest poczucie dumy z siebie, natomiast najniżej mężczyźni ocenili poczucie bycia osobą wartościową w takim samym stopniu, co inni, zaś niepełnosprawne ruchowo kobiety - poczucie zadowolenia z siebie (tab. 6).

Tab. 7. Samoocena kobiet i mężczyzn z grupy porównawczej

\begin{tabular}{|c|c|c|c|c|c|c|c|}
\hline \multirow{3}{*}{ Samoocena } & \multicolumn{4}{|c|}{ Osoby pełnosprawne ruchowo } & \multirow{3}{*}{$\begin{array}{l}\text { Maks. } \\
\text { ujemna } \\
\text { różnica }\end{array}$} & \multirow{3}{*}{$\begin{array}{l}\text { Maks. } \\
\text { dodatnia } \\
\text { różnica }\end{array}$} & \multirow{3}{*}{$\mathrm{p}$} \\
\hline & \multicolumn{2}{|c|}{ Kobiety } & \multicolumn{2}{|c|}{ Mężczyźni } & & & \\
\hline & $\mathrm{M}$ & $\mathrm{SD}$ & M & SD & & & \\
\hline T1 & 2,48 & 0,68 & 2,67 & 0,70 & $-0,161$ & 0,000 & $\mathrm{p}>0,10$ \\
\hline $\mathrm{T} 2$ & 2,43 & 0,68 & 2,75 & 0,74 & $-0,333$ & 0,042 & $p>0,10$ \\
\hline T3 & 3,29 & 0,56 & 3,50 & 0,51 & $-0,167$ & 0,000 & $p>0,10$ \\
\hline $\mathrm{T} 4$ & 2,86 & 0,36 & 3,25 & 0,53 & $-0,292$ & 0,000 & $p>0,10$ \\
\hline T5 & 3,52 & 0,51 & 3,42 & 0,50 & 0,000 & 0,107 & $p>0,10$ \\
\hline T6 & 3,00 & 0,45 & 3,08 & 0,72 & $-0,196$ & 0,113 & $\mathrm{p}>0,10$ \\
\hline $\mathrm{T} 7$ & 2,71 & 0,56 & 3,33 & 0,56 & $-0,327$ & 0,000 & $\mathrm{p}>0,10$ \\
\hline T8 & 3,38 & 0,59 & 3,42 & 0,65 & $-0,071$ & 0,036 & $p>0,10$ \\
\hline T9 & 3,48 & 0,51 & 3,29 & 0,46 & 0,000 & 0,185 & $\mathrm{p}>0,10$ \\
\hline T10 & 3,29 & 0,46 & 3,46 & 0,51 & $-0,173$ & 0,000 & $\mathrm{p}>0,10$ \\
\hline Suma & 30,43 & 2,48 & 32,17 & 4,14 & $-0,292$ & 0,042 & $\mathrm{p}>0,10$ \\
\hline
\end{tabular}

Źródło: opracowanie na podstawie badań własnych. 
Zarówno kobiety, jak i mężczyźni z grupy porównawczej byli przekonani, że w życiu im się wiedzie, są z siebie dumni, przejawiają szacunek w stosunku do własnej osoby, czują się potrzebni i wartościowi. Elementami obniżającymi globalny wynik samooceny w przypadku obu płci są obszary skoncentrowane na posiadaniu pozytywnych cech oraz uważanie siebie za osobę wartościową w takim samym stopniu, co inni (tab. 7).

Tab. 8. Samoocena osób z grupy podstawowej aktywnych i biernych zawodowo

\begin{tabular}{|c|c|c|c|c|c|c|c|}
\hline \multirow{3}{*}{ Samoocena } & \multicolumn{4}{|c|}{ Osoby niepełnosprawne ruchowo } & \multirow{3}{*}{$\begin{array}{l}\text { Maks. } \\
\text { ujemna } \\
\text { różnica }\end{array}$} & \multirow{3}{*}{$\begin{array}{l}\text { Maks. } \\
\text { dodatnia } \\
\text { różnica }\end{array}$} & \multirow{3}{*}{$\mathrm{p}$} \\
\hline & \multicolumn{2}{|c|}{ Aktywne zawodowo } & \multicolumn{2}{|c|}{ Bierne zawodowo } & & & \\
\hline & M & SD & M & SD & & & \\
\hline $\mathrm{T} 1$ & 1,95 & 0,74 & 2,06 & 0,94 & $-0,095$ & 0,048 & $\mathrm{p}>0,10$ \\
\hline $\mathrm{T} 2$ & 2,05 & 0,67 & 2,06 & 0,94 & $-0,111$ & 0,087 & $p>0,10$ \\
\hline $\mathrm{T} 3$ & 2,48 & 0,75 & 2,44 & 0,98 & $-0,119$ & 0,079 & $p>0,10$ \\
\hline $\mathrm{T} 4$ & 2,24 & 0,77 & 2,22 & 0,73 & $-0,032$ & 0,056 & $p>0,10$ \\
\hline T5 & 2,86 & 0,91 & 2,83 & 0,92 & $-0,040$ & 0,103 & $\mathrm{p}>0,10$ \\
\hline T6 & 2,24 & 0,83 & 2,11 & 0,68 & $-0,071$ & 0,198 & $p>0,10$ \\
\hline $\mathrm{T} 7$ & 2,48 & 1,17 & 2,39 & 1,04 & $-0,071$ & 0,095 & $\mathrm{p}>0,10$ \\
\hline T8 & 2,62 & 0,92 & 2,44 & 0,86 & $-0,032$ & 0,175 & $p>0,10$ \\
\hline T9 & 2,86 & 0,96 & 2,61 & 1,09 & 0,000 & 0,167 & $p>0,10$ \\
\hline $\mathrm{T} 10$ & 2,52 & 1,03 & 2,67 & 0,91 & $-0,135$ & 0,024 & $p>0,10$ \\
\hline Suma & 24,29 & 4,54 & 23,83 & 6,40 & $-0,167$ & 0,214 & $p>0,10$ \\
\hline
\end{tabular}

Źródło: opracowanie na podstawie badań własnych.

Wyniki uzyskane w badaniu pokazują, że osoby niepełnosprawne ruchowo aktywne zawodowo, w porównaniu do osób niepełnosprawnych biernych zawodowo, wyżej oceniały swoje przekonanie o własnym powodzeniu, własne umiejętności, poczucie dumy i zadowolenia, szacunek do własnej osoby. Problematyczne jest jednak dla nich spostrzeganie siebie jako osoby wartościowej w takim samym stopniu, co inni (tab. 8).

Osoby pełnosprawne ruchowo aktywne zawodowo, w porównaniu do osób z tej samej grupy, ale niepracujących, uważały, że posiadają wiele pozytywnych cech, były zadowolone z siebie, sądziły, że ogólnie im się wiedzie, lubią siebie. Największa różnica dotyczyła szacunku do własnej osoby i zadowolenia z siebie (tab. 9).

Praca zawodowa badanych osób nie jest zatem istotnym czynnikiem oddziałującym na samoocenę. Można przypuszczać, że występowanie niskiego i bardzo niskiego oraz wysokiego i bardzo wysokiego poziomu samooceny zarówno u osób aktywnych, jak i biernych zawodowo jest spowodowane wkładem jeszcze innych czynników przyczyniających się do budowania obrazu własnej osoby. 
Tab. 9. Samoocena osób z grupy porównawczej aktywnych i biernych zawodowo

\begin{tabular}{|c|c|c|c|c|c|c|c|}
\hline \multirow{3}{*}{ Samoocena } & \multicolumn{4}{|c|}{ Osoby pełnosprawne ruchowo } & \multirow{3}{*}{$\begin{array}{l}\text { Maks. } \\
\text { ujemna } \\
\text { różnica }\end{array}$} & \multirow{3}{*}{$\begin{array}{l}\text { Maks. } \\
\text { dodatnia } \\
\text { różnica }\end{array}$} & \multirow{3}{*}{$\mathrm{p}$} \\
\hline & \multicolumn{2}{|c|}{ Aktywne zawodowo } & \multicolumn{2}{|c|}{ Bierne zawodowo } & & & \\
\hline & M & SD & M & SD & & & \\
\hline $\mathrm{T} 1$ & 2,57 & 0,68 & 2,60 & 0,74 & $-0,033$ & 0,000 & $\mathrm{p}>0,10$ \\
\hline $\mathrm{T} 2$ & 2,63 & 0,81 & 2,53 & 0,52 & $-0,033$ & 0,167 & $\mathrm{p}>0,10$ \\
\hline $\mathrm{T} 3$ & 3,43 & 0,57 & 3,33 & 0,49 & $-0,033$ & 0,133 & $\mathrm{p}>0,10$ \\
\hline $\mathrm{T} 4$ & 3,03 & 0,56 & 3,13 & 0,35 & $-0,133$ & 0,033 & $\mathrm{p}>0,10$ \\
\hline $\mathrm{T} 5$ & 3,43 & 0,50 & 3,53 & 0,52 & $-0,100$ & 0,000 & $\mathrm{p}>0,10$ \\
\hline T6 & 3,07 & 0,69 & 3,00 & 0,38 & $-0,133$ & 0,200 & $\mathrm{p}>0,10$ \\
\hline $\mathrm{T} 7$ & 3,10 & 0,61 & 2,93 & 0,70 & 0,000 & 0,133 & $\mathrm{p}>0,10$ \\
\hline $\mathrm{T} 8$ & 3,37 & 0,61 & 3,47 & 0,64 & $-0,100$ & 0,000 & $\mathrm{p}>0,10$ \\
\hline T9 & 3,37 & 0,49 & 3,40 & 0,51 & $-0,033$ & 0,000 & $\mathrm{p}>0,10$ \\
\hline $\mathrm{T} 10$ & 3,40 & 0,50 & 3,33 & 0,49 & 0,000 & 0,067 & $\mathrm{p}>0,10$ \\
\hline Suma & 31,40 & 3,80 & 31,27 & 3,06 & $-0,133$ & 0,167 & $p>0,10$ \\
\hline
\end{tabular}

Źródło: opracowanie na podstawie badań własnych.

Podsumowując, niska samoocena u osób niepełnosprawnych ruchowo może wiązać się z tym, że są one ostrożne i niepewne, pragną sukcesu, choć jednocześnie obawiają się porażki. W sytuacjach nowych, które mogą stanowić dla nich wyzwanie, częściej przejawiają lęk i obawę przed niepowodzeniem i upokorzeniem, utrudniając sobie poznanie własnych możliwości i rozwój nowych kompetencji, w tym rodzicielskich i zawodowych. Częściej też ujawniają trudności $\mathrm{w}$ dokonywaniu nawet prostych życiowych wyborów. Istotnie niższa samoocena niepełnosprawnych ruchowo może przejawiać się w przeżywaniu negatywnych emocji, takich jak frustracja spowodowana trudnościami z poruszaniem się, poczucie osamotnienia i wyizolowania spowodowane ograniczeniem uczestnictwa w życiu społecznym i kulturalnym, poczucie braku nadziei i perspektyw na realizację własnych planów i aspiracji. Preferują sytuacje bezpieczne i raczej neutralne, a w sytuacjach stresowych częściej przejawiają postawę unikową wobec trudności, wyzwań i ryzyka (Dzwonkowska, Lachowicz-Tabaczek, Łaguna 2008, s. 22-23, 28-29; Borowiecki 2015, s. 125-126).

\section{ZAKOŃCZENIE}

Stresory są w życiu człowieka wszechobecne i nieuniknione, nie ma dla nich gotowych i zautomatyzowanych reakcji adaptacyjnych. Nie zawsze są to czynniki o charakterze patogennym, przeradzające się w stres i negatywne stany emocjonalne. W zależności od ich charakteru oraz od tego, czy człowiekowi uda się skutecznie zredukować napięcie, mogą również mobilizować, wyzwalać energię 
i sprzyjać zdrowiu. Wśród ważnych zasobów podmiotowych szczególnego znaczenia nabiera pozytywna samoocena, która poprawia jakość życia jednostki, sprzyja zachowaniu potencjału emocjonalnego i spokoju wewnętrznego, szukaniu sensu życia i sensu działania (Wrona-Polańska 2012, s. 17-22).

Celem niniejszego opracowania było określenie poziomu samooceny niepełnosprawnych ruchowo rodziców aktywnych i biernych zawodowo. W badaniach została wykorzystana Skala Samooceny SES M. Rosenberga. Średnie wyniki badań w zakresie samooceny osób niepełnosprawnych są istotnie statystycznie niższe od średnich wyników uzyskanych w tym zakresie przez osoby pełnosprawne.

Przeprowadzone badania zmuszają do zastanowienia się nad sposobami budowania samooceny u osób niepełnosprawnych. Stworzenie możliwości i warunków do autorefleksji jest punktem wyjścia do lepszego poznania siebie, co stanowi bazę do rozwoju własnego potencjału oraz kontrolowania swojego postępowania tak, aby stało się ono celowe i zorientowane na sukces. Ważne jest, aby osoby niepełnosprawne nauczyły się traktować pojawiające się trudności, niedociągnięcia i straty jako kolejne doświadczenia w życiu. Tylko wtedy jednostka może odzyskać kontrolę nad własnym życiem, wiarę, że można wpływać na sytuacje życiowe: niektórym zapobiegać w przyszłości, inne zaś pokonywać w sposób konstruktywny (Góralewska-Słońska 2011, s. 102, 112; Poprawa 2001, s. 112).

W budowaniu pozytywnej samooceny u osób niepełnosprawnych szczególnie ważna może okazać się również aktywność na rynku pracy, która daje szansę na większą samodzielność i niezależność ekonomiczną. Brak pracy lub jej utrata może obniżać poziom zaufania do siebie, wiarę we własną skuteczność oraz umiejętność radzenia sobie ze stresem. Osoby bezrobotne rzadziej angażują się w różne formy aktywności, częściej natomiast doświadczają konfliktów emocjonalnych związanych z oceną siebie w kategorii osób o niestabilnej sytuacji zawodowej oraz łatwiej załamują się i obwiniają w momencie doświadczania kolejnego niepowodzenia w szukaniu pracy. Szczególnego znaczenia nabiera więc rozwijanie u osób niepełnosprawnych umiejętności związanych z projektowaniem własnej ścieżki kariery zawodowej, samodzielnej oceny własnych możliwości zawodowych i wspieranie ich w kształtowaniu Ja zawodowego. Drugi obszar oddziaływań powinien obejmować szersze kręgi społeczne, a ich celem powinna być zmiana często negatywnych postaw silnie zakorzenionych w stereotypach wobec aktywności zawodowej osób niepełnosprawnych. I wreszcie istotne są odpowiednie regulacje prawne i rozwiązania ustawowe, które ułatwią osobom niepełnosprawnym podjęcie aktywności zawodowej, włączając je w nurt pracy zawodowej zgodnie z ich potencjałem i kwalifikacjami (Kirenko, Sarzyńska 2010, s. 100-101, 270). 


\section{BIBLIOGRAFIA}

Antonovsky A. (2005), Rozwiktanie tajemnicy zdrowia. Jak radzić sobie ze stresem i nie zachorować, Warszawa: Instytut Psychiatrii i Neurologii.

Aronson E., Wilson T.D., Akert R.M. (1997), Psychologia społeczna, Poznań: Wydawnictwo Zysk i S-ka.

Bochniarz A. (2017), Samoocena rodziców z niepetnosprawnościa ruchowa, [w:] D. Opozda, M. Leśniak (red.), Rodzicielstwo w wybranych zagadnieniach pedagogicznych, Lublin: Wydawnictwo Episteme.

Borowiecki P. (2015), Samoocena osób z niepetnosprawnościq w świetle wybranej literatury i badań własnych, „Niepełnosprawność i Rehabilitacja”, nr 3.

Borys B. (2010), Zasoby zdrowotne w psychice człowieka, „Forum Medycyny Rodzinnej” 2010, t. 4 , nr 1 .

Branden N. (2012), 6 filarów poczucia własnej wartości, Łódź: Wydawnictwo Feeria.

Dzwonkowska I., Lachowicz-Tabaczek K., Laguna M. (2008), Samoocena i jej pomiar. Polska adaptacja skali SES M. Rosenberga. Podręcznik, Warszawa: Pracownia Testów Psychologicznych.

Góralewska-Słońska A. (2011), Poczucie własnej wartości jako potencjał jednostki, „Problemy Profesjologii", $\mathrm{nr} 2$.

Heszen I., Sęk H. (2008), Psychologia zdrowia, Warszawa: Wydawnictwo Naukowe PWN.

Juczyński Z. (2009), Pomnażanie i wzbogacanie zasobów własnego zdrowia, „Polskie Forum Psychologiczne", t. 14, nr 1.

Kirenko J. (1998), Psychospołeczne determinanty funkcjonowania seksualnego osób z uszkodzeniem rdzenia kręgowego, Lublin: Wydawnictwo UMCS.

Kirenko J., Sarzyńska E. (2010), Bezrobocie. Niepetnosprawność. Potrzeby, Lublin: Wydawnictwo UMCS.

Kirenko J., Wiatrowska A. (2015), Otyłość. Przystosowanie i uwarunkowania, Lublin: Wydawnictwo UMCS.

Łaguna M., Mielniczuk E., Żaliński A., Wałachowska K. (2015), Przywiąanie do organizacji i zaangażowanie w prace - koncepcje teoretyczne i problemy terminologiczne, „Medycyna Pracy", nr 66(2).

Łobocki M. (2006), Wprowadzenie do metodologii badań pedagogicznych, Kraków: Oficyna Wydawnicza „Impuls”.

Majewicz P. (2002), Obraz samego siebie a zachowanie młodzieży niepetnosprawnej ruchowo, Kraków: Wydawnictwo Naukowe Akademii Pedagogicznej.

Marszałek L. (2006), Niepetnosprawność. Kobiecość. Rodzina, Warszawa: Wydawnictwo Uniwersytetu Kardynała Stefana Wyszyńskiego.

Ogińska-Bulik N., Juczyński Z. (2010), Osobowość. Stres a zdrowie, Warszawa: Difin.

Poprawa R. (2001), Zasoby osobiste w radzeniu sobie ze stresem, [w:] G. Dolińska-Zygmunt (red.), Podstawy psychologii zdrowia, Wrocław: Wydawnictwo Uniwersytetu Wrocławskiego.

Sęk H. (2001), Stres krytycznych wydarzeń życiowych, [w:] H. Sęk, T. Pasikowski (red.), Zdrowie stres - zasoby, Poznań: Wydawnictwo Fundacji Humaniora. 
Wrona-Polańska H. (2012), Psychologia zdrowia w stużbie człowieka - rola zasobów podmiotowych, [w:] H. Wrona-Polańska (red.), Psychologia zdrowia w stużbie człowieka, Kraków: Wydawnictwo Naukowe Uniwersytetu Pedagogicznego.

Wrona-Polańska H., Kaczmarska A.M. (2012), Zasoby podmiotowe i radzenie sobie ze stresem a poziom zdrowia pacjentów po przeszczepie szpiku kostnego, [w:] H. Wrona-Polańska (red.), Psychologia zdrowia w stużbie czlowieka, Kraków: Wydawnictwo Naukowe Uniwersytetu Pedagogicznego.

\section{SUMMARY}

Professional work is a significant part of life of an individual. It assures economic safety, enables to fulfill needs, to build identity, to find a sense and purpose and contributes to development and constant learning. Unfortunately, still, a lot of people experience limitations in accessing work. People with disability are especially affected. For them, professional activity is an opportunity to compensate for the limitations resulting from a given disability, but it is also an important factor to build their self-esteem. The main focus of the empirical analysis are issues related to a self-esteem of people with movement disability who are working parents. The method which has been used is the Rosenberg Self-Esteem Scale in the Polish adaptation of I. Dzwonkowska, K. Lachowicz-Tabaczek, and M. Łaguna.

Keywords: generalized resistance resources; self-esteem; stressors; critical life situations; movement disability; work; family 